\title{
Ortaçağ Bulgaristanı'nda Sapkın Bir Hareket: Bogomilizm
}

\section{A Heretical Movement in Medieval Bulgaria: Bogomilism}

\author{
Murat Serdar ${ }^{1}$ (), Murat Hanar $^{2}$ (1)
}

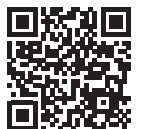

'Sorumlu yazar/Corresponding author: Murat Serdar (Doç. Dr.), Tokat

Gaziosmanpaşa Üniversitesi, Fen-Edebiyat Fakültesi, Tarih Bölümü, Tokat, Türkiye.

E-posta: mserdar61@live.com

ORCID: 0000-0003-2922-1096

${ }^{2}$ Murat Hanar (Doktora Öğrencisi), Tokat Gaziosmanpaşa Üniversitesi, Lisansüstü Eğitim Enstitüsü, Ortaçağ Tarihi Bilim Dalı, Tokat, Türkiye.

E-posta: murathanar@gmail.com

ORCID: 0000-0002-1495-7183

Başvuru/Submitted: 02.10.2020 Revizyon Talebi/Revision Requested: 20.02.2021

Son Revizyon/Last Revision Received:

27.02.2021

Kabul/Accepted: 28.03 .2021

Atıf/Citation: Serdar, Murat, Hanar, Murat, “Ortaçağ Bulgaristanı'nda Sapkın Bir Hareket: Bogomilizm", Güneydoğu Avrupa Araştırmaları Dergisi, 36 (2021), s. 17-33 https://doi.org/10.26650/gaad.804486

\section{öz}

İnanç, insanların hayattaki en temel gereksinimlerinden birisidir. Dünyada her dinin kendine göre bir inanç sistemi olsa da hemen hemen hepsinde zamanla o dinin emirlerinin sorgulandığı olmuştur. Bu sorgulama inancımıza göre hak din olarak kabul ettiğimiz semavi dinlerde de olmuştur. Bilhassa Hıristiyanlık, konsillerle zaman içerisinde farklı mezheplere ayrıımış ve bu ayrışımdan sonrasında bile insanların beklentileri tam anlamılla karşılanamamıştır. İnanç üzerine karşılanamayan bu beklentiler yeni oluşumların ortaya çıkmasına sebebiyet vermiştir. Bu oluşumlar ortaya çıkarken evvelki inanç sistemlerinden kalan ve insanların bir türlü terk edemedikleri ritüelleri ya da inanışları mevcut hak dinlerin içerisine yerleştirilmeye çalışılmışlardır. Her din kelime olarak farklı adlandırsa da bunların ortak noktası sapkın olmalarıdır. Bizim de konu olarak ele alacağımız Bulgaristan topraklarında ortaya çıkan Bogomilizm'dir. Rahip Bogomil'den ismini alan bu inanış tarzı, büyük oranda Maniheizm'den etkilenmiş ve şeytanı, inanış merkezine yerleştirmiştir. Bogomilizm zaman içerisinde Balkan topraklarından çıkarak hem Bizans sınırları içerisinde hem de Doğu ve Batı Avrupa'da yayııma imkânı bulmuştur. Yayılım gösterdikleri bölgelerde bunlara dair sıkı önlemler alınmıştır. Bogolimizm' in yayılışı, alınan tedbirler ve uyulması gereken tavsiyelere dair bilgi veren üç kaynak günümüze ulaşmayı başarmıştır. Bogomilizm bu inançla bölgede nasıl bir yayılım göstermişler? Bölgede yaşayan Hristiyan yerel halkın Bogomillere karşı tutumu ne olmuştur? Dini ve siyasi erkler ne gibi önlemler almıştır? Bu sorulara cevap bulabilmek için İstanbul Patriği Theophylact'ın mektubu, Cosmas adında bir Bulgar rahibin mektubu, Çar Boris yönetiminde Bogomilleri kınayan bir kilise fermanından ve diğer çalışmalardan faydalanacağız.

Anahtar Kelimeler: Bogomilizm, Bulgaristan, Balkanlar, Heretik, İnanç

\section{ABSTRACT}

Faith is one of the most basic needs of people in life. Although every religion in the world has its own belief system, almost all of them have been questioned over time. This questioning occurred in the heavenly religions that we accept as the true religion according to our belief. In particular, Christianity was 
divided into different sects over time with the councils and even after this separation, people's expectations were not fully met. These expectations, which could not be met on faith, led to the emergence of new formations. While these formations were emerging, they tried to place the rituals or beliefs that remained from the previous belief systems and which people could not abandon, into the existing true religions. Although each religion names them differently as words, their common point is that they are perverted. It is Bogomilism that emerged in the territory of Bulgaria, which we will deal with as a subject. This belief style, named after the priest Bogomil, was greatly influenced by Manichaeism and placed the devil in the center of belief. Bogomism emerged from the Balkan lands in time and had the opportunity to spread both within Byzantine borders and in Eastern and Western Europe. Strict measures have been taken in the regions where they spread. Three sources providing information about the spread of Bogolism, the measures taken and the recommendations to be followed have managed to reach today. How did Bogomism spread in the region with this belief? What was the attitude of the Christian local people living in the region towards the Bogomil? What measures have religious and political powers taken? To find answers to these questions, we will benefit from the letter of the Patriarch of Istanbul, Theophylact, the letter of a Bulgarian priest named Cosmas, a church edict condemning the Bogomils under Tsar Boris, and other studies.

Keywords: Bogomilism, Bulgaria, the Balkans, Heretics, Faith

\section{EXTENDED ABSTRACT}

Undoubtedly, one of the most basic needs of human beings since the day they existed is belief. Therefore, a history of humanity without belief is absolutely unthinkable. Beliefs have constantly changed and varied throughout history. Each new belief that emerges has brought new powers and new interpretations and new formations with them. It is possible to verify this with various examples: sects in the heavenly religions are the most obvious example of this. However, these interpretations and occurrences sometimes reached extreme points and were sometimes described as heretic. This diversity of beliefs has reached different dimensions that can be called heretic, sometimes due to geography, sometimes to culture, and sometimes to the thoughts of a respectable person.

One of these heretic currents are Bogomils. By bringing new interpretations, different approaches to Christianity, they developed a perverted view. Although it is thought to have originated in the Bulgarian geography, it was developed by Priest Bogomil and spread over a wide geography in a short time. It is clear that the Bogomils had seriously different religious interpretations and that they developed a belief with contrary views of that period. The Bogomil believed that the Prophet Jesus was born from the Virgin Mary, was crucified and ascended to the sky, but that the Prophet Adam and Eve were not created by God, but by Satan, and that the Old Testament was written by Satan. The different ways of praying, attitudes towards icons, and attitudes towards clergy did not match up with the basic views of Christianity. For this reason, Bogomils were cursed, excommunicated and punished in 1167 Kathar Council. This was normal and common in the medieval period.

However, when we look at the geography where it has spread and when we look at the people who follow this belief, we can easily see that these are in fact socially low, living 
standards are not developed, and continue their lives in rural areas. People in this stratum were generally traditionalists, closed to innovations and especially those who could not adapt to Christianity. Such people are already present in many regions, different religions and cultures. It is not an easy situation to break away from the ancestors cult and to adopt a new belief and to try to adapt to its rules. Those who adopt new beliefs will surely bring something new from their old beliefs and want to add to these new beliefs. Therefore, it is not quite possible to say that anyone has given up their old belief completely, because reading one's inner world, reading intentions, is one of the most difficult jobs in the world. We can only comment on what the person has done. It is a very natural situation that people who change their beliefs cause problems in their region or are seen as a threat by those in the region. For this reason, they may be under constant pressure and even be forced to leave their homeland.

Despite all these negativities, we can easily say that new formations are pregnant with new pains and this birth often fails. Apart from this, it is sometimes stated that the Bogomils are not worth investigating by some historians, but it is a fact that such movements have nestled and reappeared in different periods even in the periods when they were suppressed throughout history. As the most frequent example of this, where the Knights Templar was said to be over in the XIV. century, after the execution of Louis XVI. after the French Revolution, a citizen went up to the execution platform and shouted, "The revenge of Jacques de Molay was taken". It is understood from here that although centuries have passed, such currents have not completely disappeared and have somehow continued their existence. 


\section{Bogomilizm'in Ortaya Çıkışı}

Bogomil sapkınlığı, Ortaçağ'ın sonuna kadar bozuk olarak görülen Ortodoks Kilisesi için sonuncu düalist sapkınlıktır. Popüler dindarlık, gelenek ve batıl inançlardan beslenen Bogomilizm X. yüzyııın başlarında Hıristiyanlığın bir mezhebi olarak Bulgaristan'da ortaya çıkmış ve Doğu Ortodoks Kilisesine göre heretik bir akım olarak kabul edilmiştir. XI. ve XII. yüzyılların felsefik sapkınlıklarılla hiçbir ortak yanı bulunmayan bu heretik akım, ismini Rahip Bogomil'den almıştır.' Düalist olan bu akıma göre Tanrı'ın (Yaratııı) iki oğlu bulunmaktadır. Dünyanın ve insanın yaradıışı ile insana ruh verilişi büyük oğul Satail'e verilmiş ama o Tanrı'ya isyan etmiştir. İnsanlığı şeytanın esaretinden kurtarmak için Tanrı, ikinci oğlu İsa'yı insan suretinde dünyaya göndermiştir. İsa, Şeytan'a karşı zafer kazandıktan sonra gökyüzüne dönmüş, arkasında ise gerçek Hıristiyanlar olan Bogomillere yardım etmek üzere kutsal ruhu bırakmıştır. Yeni Ahid'i kabul eden Bogomiller, Eski Ahid'in bazı kısımlarını şeytanın eseri diye reddettikleri gibi evliliği ve et yemeyi de reddederler. Ayrıca ikonlara saygı göstermeyi putperestlik olarak kabul etmekle birlikte Katoliklerin kiliselerini kötü ruhların mabetleri olarak görmektedirler. ${ }^{2}$

Bogomilizm Bulgaristan'da ortaya çıkıktan sonra, farklı şekillerde Balkan Yarımadası, Anadolu, İtalya hatta Fransa'ya kadar yayılmıştır. Çok sayıda taraftar ve destekçi bulmasıyla önce Bizans İmparatorluğu'nun birçok bölgesinde hızlı bir şekilde yayılmış ve XI. yüzyılın sonu ile XII. yüzyılın başında Bizans başkenti çok sayıda Bogomil inancını taşıyan kişiyle tanışmışır. Torba taşıyanlar ve gezginler gibi lâkapların yanında, bu heretiklere Bulgarca "Bogomiller" denilmiştir. 0 günlerde Bizans İmparatorluğu ve Bulgaristan'daki sosyal ve ekonomik durumun birbirine benzemesi, Bogomillik hareketinin imparatorluğun her tarafına yayılmasına zemin hazırlamıştır. Bogomiller, kendilerini yöneten yabancı güçlere karşı insanları kışkırtmakta etkili olmuşlar ve zamanla inanç ve hareketlerini Bizans İmparatorluğu'nun dışına taşımışlardır. Sosyal düzenin ve feodal sistemin iki hamisi olan Kilise ve Devlet'in aleyhine öne sürdükleri düşünceler, Bogomilleri halk nezdinde geniş bir üne kavuşturmuştur. XI. yüzyllda Bogomiller, Sırbistan'a yayıldıklarında, bölgede feodal beyler hüküm sürmekteydi. Sırp Kralı Çoban Stefan Nemanje'nin idaresi döneminde heretikler güç kazanmışlar ve bu durum, onlara karşı acil tedbirler almayı gerekli kılmıştır. 14 Ağustos 1167 Pazartesi günü Saint-Felix-de-Caraman'da (Fransa) toplanan Kathar konsilinde bu heretikler lanetlenmiş, aforoz edilmiş ve cezalandırılmışlardır. ${ }^{3}$ Daha sonra da Stefan Duşan onlara karşı yaptııımlar içeren özel bir kanun çıkarmışıı. 4 Bulgaristan ve Sırbistan'ın haricinde Bogomillerin Makedonya topraklarında da faaliyet gösterdikleri görülmektedir. Bu hususta Theophylact'ın mektubu bize bilgi verse de

1 Vassil A. Vassilev, Bulgaria 13. Centuries of Existence, Sofia: Sofia Press, 1979, s. 41; Michael Angold, "The Bogomils", Church and Society in Byzantium under the Comneni, 1081-1261, Cambridge: Cambridge University Press, 1995, s. 468.

2 Mehmet Aydın, “Hıristiyanlık: Mezhepler ve Tarikatlar", C. XVII, DiA, İstanbul, 1998, s. 356.

3 Bu konuda daha geniş bilgi için bkz: Edwar Peters, Heresy and Authority in Medieval Europe, Phiadelphia: University of Pennsylvania Press, 1980, s. 121-123.

4 Lütfi El-Mi'veş, “Bogomiller, Hıristiyanlar ve Bosna”, (Çev. Kadir Albayrak), Tezkire, Ocak/Nisan 36-37 (2004), s. 183-184. 
mektubun yazarından daha evvel bu bölgeye gelerek sapkın inançlarını yaydıkları bilinmektedir. Bilhassa Ochrid (Ohrid/Osmanlı İmparatorluğu'nun adlandırmasıyla Ohri) bölgesinde faaliyet gösteren Bogomillere karşı şehir halkı Azizleri Clement'in şefaatine sığındığı ve ondan yardım beklediği görülmektedir. ${ }^{5}$

Bogomiller, Katharlar ve Pavlusçuların Trakya'da ortaya çıkmış olan bir koluydu. Bazı tarihçilere göre bu heretik mezhepler, ilk dönemlerinde tamamen Baptist'tirler. Bu, onların sadece vaftiz ve ekmek şarap ayinine karşı olan olumsuz tavırlarından değil, kilise hiyerarşisine, Bakire Meryem ve azizlere tapınmaya, bağımsız bir kiliseye bağlanmaya karşı olmalarından da anlaşılmaktadır. ${ }^{6}$ Bundan dolayı da Bosna, Bulgaristan ve Ermenistan Hıristiyanlarının, ilk apostolik Hıristiyan Kilisesinin izleyicileri olmaları ihtimali çok yüksektir. Bununla birlikte bir kısım Katolik araştırmacılar Bogomillerin vaftizi uygulamadıklarını, ekmek-şarap ayinine saygı göstermediklerini, üstelik onların Eski Ahid'i inkâr ettiklerini iddia etmişlerdir. Belki de bu onların ergenlikten önceki çocuk vaftizine karşı olmaları, referans olarak da Yeni Ahid'i kutsal metin kabul etmeleri anlamına gelmektedir. Bogomiller, kiliseye aykırı düşen bu inanç eğilimlerinden dolayı kısa sürede kovuşturmalara uğramış ve çeşitli zulümlere maruz kalmışlardır. Buna rağmen Ortaçağ'da hatta XVI. yüzyılda da varlıklarını sürdürmüşlerdir. Bogomillere karşı uygulanan bu şiddet politikaları uzun süre sert bir şekilde devam etmiş fakat bu baskılar onları yok etmemiş, onların yer altına çekilmelerine sebep olmuştur. Böylece Bogomiller bütün Avrupa'da özellikle de Ren Nehri boyunca Balkanlarda gizlenmişlerdir. Dolayısıyla bu yer altına gizlenen oluşumlar uygun bir fırsatta ortaya çıkmak için zaman kollamışlardır. ${ }^{7} \mathrm{Bu}$ fırsat kendini Avrupa'daki reform hareketleriyle ve bilhassa Anabaptist, Uniteryen görüşler şeklinde kendini göstermişstir. Bu konunun ne şekilde tezahür ettiğini daha iyi anlayabilmek için Bogomilizm'in teolojik yönünün bilinmesi gerekmektedir.

\section{Bogomilizm'in Teolojik Yönü}

Bulgaristan'daki Bogomillerle ilgili üç ana kaynak mevcuttur. Bu kaynaklar İstanbul Patriği Theophylact tarafından yaklaşık 940 yılında Çar Peter'a yazılan bir mektup; Cosmas adında bir Bulgar rahip tarafından sapkınlığa karşı yazılmış bir mektup (muhtemelen yaklaşık 970'te) ve 1211 'de Çar Boris yönetiminde Bogomilleri kınayan bir kilise fermanından ibarettir.8

5 Bu hususta daha geniş bilgi için bkz: Giorgio Nurigian, The Macedonian Genius Through The Centuries, London: David Harvey Publishers, 1972, s. 66.

6 Aslında Hıristiyanlığın ayrışmasıyla ilgili pek çok kaynak mevcuttur fakat kanaatimizce ülkemizde bu alanda yapılan en derli toplu ve başarılı çalışmalardan biri Turhan Kaçar'ın eseridir. Hıristiyanlık ve ayrışma dönemleri için mezkur çalışmaya bakılabilir: Turhan Kaçar, Geç Antikçağ'da Hıristiyanlık, İstanbul: Arkeoloji ve Sanat Yayınları, 2009, s. 52.

7 Anna Komnena, Bogomillerin yer altına gizlenmesiyle ilgili ilginç bir benzetme yapmaktadır: “işte bu, yılanlar gibi delikler içinde toprağa gizlenen karanlıklar dünyası soyunu..." devamı aslında daha ilgi çekicidir çünkü Anna Komnena babasının, Bogomilleri nasıl yendiğini gururlu bir dille aktarmaktadır. Bkz. Anna Komnena, Alexiad, (Çev. Bilge Umar), Ankara: İnkılâp Kitabevi Yayınları, 1996, s. 507-508.

8 John Van Antwerp Fine, The Early Medieval Balkans: A Critical Survey from the Sixth to the Late Twenlfth Century, Michigan: The University of Michigan Press, 1991, s. 171. 
Theophylact'ın mektubu, patriğin sapkınlıkla nasıl başa çıkılacağına dair tavsiyede bulunmasını isteyen Çar Peter'ın günümüze ulaşmayan bir mektubuna yanıt olarak yazılmıştır. Muhtemelen Theophylact'ın mektubunda verilen sapkın inançlarla ilgili açıklamalar, Peter'ın ilk mektubundan alınmıştır. Patrik mektubunda, Bulgaristan'da ortaya çıkan ve adı verilmeyen yeni bir sapkınlığa atıfta bulunmaktadır. Patrik, sapkınlığın iki ilkeye dayandığını iddia etmektedir: Bu görüşlerin birincisi Tanrı'nın ışığı ve görünmez dünyayı, ikincisi ise karanlığı, maddeyi ve insan vücudunu yarattığıdır. Heretikler, Eski Ahid, evlilik, üreme ve Mesih'in enkarnasyon gerçeğini reddetmiş; bunların şeytanî ilkeden türetildiğini söylemişlerdir. Sapkınlık çok eskidir fakat Maniheizm ve Pavlikanlık bir karışımı olarak bu dönemde de yeniden ortaya çıkmıştır. ${ }^{9}$

Paulikanlık, genellikle düalist olarak tasvir edilen ama yakın zamanda N. Garsoian tarafından adoptionist bir hareket olarak gösterilen doğulu bir sapkınlıktı. Adoptionistler, Mesih'in Tanrı tarafından kabul edilip, vaftiz zamanında lütufla ilahlaştırılıncaya kadar sadece bir insan olduğuna inanırlar. Paulikanlar, Ermenistan ve Doğu Anadolu'da yoğun olarak yaşıyorlardı. Yıllar geçtikçe pek çok imparator tarafından doğudaki sayısal üstünlüklerini kırmak ve aynı zamanda mükemmel savaşçılar olduklarından Trakya sınırını savunmak için Balkanlara nakledilmişlerdir. Birçoğu Bulgaristan sınırına yakın Filibe bölgesine yerleşmiştir. Paulikanlar genellikle Bulgar Bogomilizm'nin ortaya çıkışında büyük rol oynamışlardır. Paulikanlar gerçekten düalist (böyle bir rol mümkündür) ya da adoptionistler olsalardı, işte o zaman Bogomilizm için yerli bir köken aranması gerekirdi. ${ }^{10}$

Paulikanlar, Bulgarların Hıristiyanlığı kabul ettikleri dönemde, Bulgaristan'da sürgün olarak göçmen durumunda yaşamaktaydılar. Böylece, Maniheistlerin vaftizi terk ettiklerini açıklamalarında, genç Bulgar Kilisesi'nin çabası ve bazı tahrikleri olmuştur. Bunun üzerine Çar Piérre, başpiskopos Theophylact'tan, yeni dine dönenler için bir din değiştirme formülü talep etmiştir. Ona verilen yanıt, onların inandıkları öğretiler üzerinde bizi bilgilendirmektedir; mezhebin başkanlarını ve havarilerini resmen yadsıyarak inanç değiştirmeyi zorunlu görenler Maniheistler ve Paulikanlardır. Bogomil sapkınlığı böyle bir ortamda doğmuştur. Böylece Çar Piérre'in döneminde Bogomil'in havariliği başlamış oluyordu. Onların öğretileri kısa sürede, asıl merkez olan Filibe'den tüm Balkan Yarımadası'na ve XII. yüzyıla doğru İstanbul'a kadar yayıldı. Bogomiller, I. Aleksios Komnenos (1081-1118) ve ardılları tarafından şiddet kullanılarak bastırılmaya çalışılmıştır. Bogomilizm'in Bulgaristan'daki gelişimi Asen hanedanı yönetiminde, Sırbistan'da ise Etienne Nemmanja döneminde kayda değer biçimde artmıştır. Bununla birlikte her iki ülkede de kitleler halinde baskıya uğratılmış ve diri diri yakılmışlardır.

9 Mektup hakkında detaylı bilgi için bkz. Janet Hamilton vd., Bizans Döneminde Hıristiyan Düalist Heretikler (6501405), (Çev. Leyla Kuzucular), Ankara: Yurt Kitap-Yayın, 2011, s. 178-183; Marc de Groote, “An Anonymous Sermon against the Hagarenes, the Bogomils, and the Jews", The Harvard Theological Review, Vol. 97,3 (July 2004), s. 331.

10 Ünlü Bizans tarihçisi Garsoian, Pavlusçuluğun tüm toplumlarda kendini gösterdiğini, bunun bir türevinin de Bogomiller olduğunu ileri sürmektedir. Bkz. Nina G. Garoian, Byzantine Heresy: A Reinterpretation, Washington: Dumbarton Oaks Center for Byzantine Studies, 1971, s. 89-91. 
Daha sonra Bogomiller Bosna'ya göçmüşlerdir; burada Ban Kulin (1191-1204) ve ailesi, onlara bağlı yandaşlarıyla birlikte Bogomil inancına mensup on binlerce kişiyi ülkelerine kabul etmişlerdir. Bogomiller orada bir kilise örgütü kurmuşlar ve Banlar tarafından korumaya alınan Bogomillerin kilisesi resmen tanınmıştır. ${ }^{11}$

Sapkınlıkla ilgili en iyi ve en ayrıntılı kaynak, sapkınlıkla doğrudan tanışan ve sofistike bir teolog olmama avantajına sahip olan Bulgar rahip Cosmas'ın mektubudur çünkü çoğu Bizanslı antiheretik kaynaklar, sapkınlıkları klasik isimlerle çağırma eğilimindedirler ve daha sonra okuyucuya, heretik konularını tartışırken hem yeni ve alakalı hem de klasik ve alakasız inançların bir karışımını vermektedirler. ${ }^{12}$

Cosmas, Peter döneminde, Bogomil adında (Tanrı'nın merhametine layık anlamında) bir rahip olduğunu belirtmekle birlikte onun aslında Bulgar topraklarında sapkınlık vaazlarında bulunduğunu iletmektedir. Cosmas, heretiklerle ilgili mektubunda bizi şu ifadelerle aydınlatmaktadır: “Görünüşte, sapkınlar koyun gibidir; hoşgörülü, alçak gönüllü ve suskundurlar; boş sözler söylemez veya kendilerini gerçek Hıristiyanlardan ayıracak şekilde gülmez veya davranmazlar fakat içinde yırtıcı kurtlar da vardır. Bu tipler cahil birini bulduklarında öğretilerini bilinçsizce yayar ve Kutsal Kilise tarafından aktarılan öğretilere küfrederler. Onlar şeytanlardan daha kötüdür çünkü iblisler Mesih'in haçından ve Tanrı'nın imgelerinden korkarlar. ${ }^{33}$ Heretikler ikonlara saygı göstermezler ama kendi simgelerine taparlar. Heretikler azizlerin emanetleri ile alay eder ve onların önünde ibadet ettiğimizde bizi küçük görürler. Onlar, Kutsal Ruh'un gücü sayesinde azizlerin emanetlerini onurlandırmayı ve Tanrı́nın mucizelerini küçümserler; mucizelerin Tanrı'nın isteği ile değil, onların insanları baştan çıkartan şeytan tarafından meydana geldiğini söylerler. ${ }^{14}$

Bogomiller, Tanrı'nın değil, şeytanın görünür dünyanın yaratıcısı olduğunu iddia etmektedirler. ${ }^{15}$ Bogomiller, bir insanın çarmıha nasıl tapabileceğini sorarlar? Yahudilerin Tanrı'nın Oğlu'nu çarmıha gerdikleri açıktır. Bu nedenle Haç, Tanrı'nın düşmanıdır. ${ }^{16}$ Heretikler taraftarlarına, birinin kralın oğlunu bir parça odunla öldürmesi durumunda, o odunun kral için değerli olup olmayacağını söyleyerek, Haç'tan nefret etmelerini öğretiyorlardı. ${ }^{17}$ Cemaatin Tanrı'nın emriyle kurulmadığını ve Efkaristiya'nın aslında Mesih'in bedeni değil, diğerleri gibi basit yiyeceklerden oluştuğunu söylemektedirler. Rahiplerin sözlerinin Tanrı tarafından kutsanmış olduğuna

11 İsmail Kaygusuz, “Anadolu'dan Batı Avrupa'ya, Aykırı İnanç ve Düşünce Geleneği ve Alevilikteki Kalıtlar”, Müslüman ve Hıristiyanlığın Inanç Öğretilerinde Öteki Gerçekler, İstanbul: Su Yayınları, 2006, s. 189-190.

12 Rahip Cosmas'ın söylevi için bkz. Hamilton vd., Bizans Döneminde, s. 205-234.

13 Hamilton vd., Bizans Döneminde, s. 207.

14 Fine, The Early Medieval Balkans, s. 173.

15 Kadir Albayrak, Bogomilizm ve Bosna Kilisesi, İstanbul: Emre Yayınları, 2005, s. 75.

16 Cosmas bu düşünceyi şöyle savunur: “Tanrı'nın oğlunu ağaçtan yapılma bir haç üzerinde öldürdülerse, o ağaç Tanrı'dan kıymetli olamaz. Aynı şey Tanrı'nın haçı için de geçerlidir."Bkz. Hamilton vd., Bizans Döneminde, s. 211.

17 Groote'ın sorusu manidardır: "Öyleyse, Haç’ı kim sevmek zorundadır?” Bkz. Marc de Groote, "An Anonymous Sermon against the Hagarenes, the Bogomils, and the Jews", The Harvard Theological Review, Vol. 97,3 (July 2004), s. $329-334+336-351$ s. 338. 
inanmıyorlar. Rahiplerin olması gerektiği gibi yaşamadıklarına inanırlar. Rahiplere, kiliselere, dualara karşıdırlar (Tanrı'nın Duası hariç) ve Musa'nın emirleri ile peygamberlerin kitaplarını reddederler. Meryem Ana'yı onurlandırmazlar. Meryem Ana'ya yapılan dualar için, Cosmas'ın bile tekrarlayamayacağı büyük bir saçmalık derler. Bununla birlikte Ortodoksluğa dönenlerin bize bildirdikleri gibi, insanlardan korktukları için kiliseleri sık sık ziyaret ederler, haçı ve ikonları öperler. Derler ki ikonlara (ve benzerlerine) sunduğumuz tüm saygı, kalpten değil, insanlar yüzündendir. İnançlarını gizlerler. ${ }^{18}$ Eski Ahid'i kabul etmeyip, sadece İncil'i kabul etmektedirler. Musa'nın Yasasına göre değil, Havarilerin yasalarına göre yaşarlar. Şeytanı insanların ve tüm ilahi oluşumun yaratıcısı olarak kabul ederler; bazıları ona yeryüzüne inmiş bir melek der. Cosmas daha sonra onu yaratıcı yaptıklarından ötürü şeytana ibadet ettiklerini anlatmaya devam eder. ${ }^{19}$

Balkanlar hakkında yaptığı çalışmalarla ardından gelenlere yol gösteren John Van Antwerp Fine The Early Medieval Balkans: A Critical Survey from the Sixth to the Late Twenlfth Century adlı eserinde Bogomiller hususunda da bizlere aydınlatıcı ve yönlendirici bilgiler vermektedir. Fine bu eserde Bogomiller hususunda şunları söylemektedir: “Bogomiller, zehirlerini alçak gönüllülük ve riyakârlıktan uzak durma perdesinin altında yayar ya da Incilleri ellerinde tutarak, saygısız yorumlar yaparlar ve bu yollarla insanları tuzağa düşürmeye çalışırlar. Gökyüzünün, güneşin, yıldızların, havanın, dünyanın, insanların, kiliselerin, haçın ve yeryüzünde hareket eden her şeyin şeytanın isteğiyle olduğunu söylerler. Tanrı'nın iki oğlu vardır. İsa yaşlıdır ve şeytan daha gençtir. Erkeklere eş almaları, et yemeleri ve şarap içmeleri emrini veren şeytandır (Mammon). Kendilerini cennetin sakinleri olarak adlandırırlar; [Ortodoks rahipler] hayatın tüm zevklerinden kendilerini mahrum bırakmıyorlar çünkü bu eylemlerin saf olmadığını iddia ediyorlar. Tanrı'nın dünyayı yarattığına inanan Ortodoks Hıristiyanlar için bu eylemlerde hiçbir şey saf değildir. Cosmas şarabın ılımlı olarak iyi olduğunu söylerken, heretikler şaraba ve ete dokunmayı kesinlikle yasaklamaktadırlar. Vaftiz edilmeyi reddeder ve vaftiz edilen bir çocuktan nefret ederler. Kendilerine Hıristiyan diyorlar ama onları vaftiz edecek rahipleri bile yok. Haç işareti yapmazlar ya da rahiplerin ilahilerini kabul etmezler ve rahipleri onurlandırmazlar. İsa Mesih'in mucizelerine inanmazlar hatta şeytanın, bu mucizeleri yazan kişinin olduğunu iddia ederler."20

Bir günde, gündüz dört ve gece dört kez olmak üzere eve kapanarak dua ederler. Dua ederken sadece "Babamız" derler. ${ }^{21}$ Tanrı'nın değil, insanların, Kilisenin ve Hıristiyanların ayinleri ve uygulamaları başlattıklarına ve bunların İncil'de yer almadığına inanırlar. Heretikler kilise bayramlarını kutlamazlar. Martirleri ve azizleri anmazlar. Ortodokslardan gelen sorularla karşılaştıklarında sapkınlıklarını inkâr ederler ve Ortodoks inancını doğrularlar ve

18 Hamilton vd., Bizans Döneminde, s. 220.

19 Prof. Lambert'e göre Bogomillerin halk arasında destek bulmasının altında yatan temel sebep, bu akımın sorduğu şu soruda ve getirdikleri çözümde yatmaktadır: “ìi bir Tanrı neden dünyada kötülüğe yer vermiştir?” Bkz. Malcolm D. Lambert, Ortaçağda Dinsel Sapkınlıklar, (Çev. Erdem Gökyaran), İstanbul: Kabalcı Yayınları, 2015, s. 82.

20 Fine, The Early Medieval Balkans, s. 174.

21 Hamilton vd., Bizans Döneminde, s. 229. 
bunu yemin ederek yaparlar. Onlara sorarsanız kendi uygulamalarını inkâr edeceklerdir; bunu şu kurnazlıkla yaparlar, eğer işlerimiz ve uygulamalarımız insanlar tarafından bilinirse tüm emeklerimiz kaybolacaktır, derler. Günahlarını birbirlerine düzenli olarak itiraf ederler ve kendi aralarında itiraflarda bulunurlar. ${ }^{22}$

Ayrıca onlar, Tanrı'nın “Tarlada çalışarak kendinizi yormayın, ne yiyeceğimizi, içeceğimizi veya giydirileceğimizi hiç düşünmeyin" dediğini söyleyerek insanların din değiştirmelerini sağlar. Bu yüzden bazıları dilenci olur ve herhangi bir işte çalışmak istemez. Evden eve giderler ve başkalarının mallarını yiyip bitirirler. Destekçilerine otoriteye boyun eğmemelerini öğretirler; zenginleri kötülerler; imparatorlardan nefret ederler; rahipleriyle alay ederler ve lordlarına hakaret ederler. Tanrı'nın imparator adına çalışanlardan nefret ettiğini iddia ederler ve tüm hizmetçilerin efendileri için çalışmamasını tavsiye ederler. ${ }^{23}$

200 yıl sonra yazılan üçüncü ana kaynak (1211), Boris (1207-18) adlı Bulgar hükümdarın Bogomillere karşı topladığı bir Sinod'un emirleridir. Eserde, şeytanın tüm Bulgar topraklarını Maniheistlerin sapkınlığı ile ektiğini ve onu Messalianlarla ${ }^{24}$ karıştırdığını söyler. İmparator Peter döneminde Rahip (Pop) Bogomil, bu Maniheist sapkınlığını almış ve onu Bulgar topraklarına yaymıştır. Heretikler, Mesih'in Meryem'den doğduğuna, çarmıha gerildiğine ve bedeninin yükseldiğine sadece görünüşte (gerçekte değil) inanmaktadırlar. Şeytan, görünen her şeyin hatta Âdem ile Havva'nın yaratıcısıydı. Heretikler, Musa'yı, peygamberleri ve patrikleri reddeder ve Eski Ahit'teki yazıların Şeytan'ın sözlerini içerdiğini iddia ederler. Eski Ahit'i de reddederler. Kadın, Şeytan'ın yardımıyla gebe kalır ve şeytan orada kalır ve vaftizle değil, dua ve oruçla kovalanır. Vaftizci Yahya'yı ve vaftizini reddederler; toplanmaya ve kiliselere karşı çıkarlar, tek duaları “Babamız”dır ve bu sözün söylendiği yer önemli değildir. Rahipliğe, cemaate, Hıristiyan gizemlerine, haçlara ve ikonlara karşıdırlar. ${ }^{25}$

Yukarıda tartışılan üç kaynak, Bogomil sapkınlığının düalist bir kaynak olduğunu açıkça göstermektedir. Bu sapkınlık Bulgaristan'dan Bizans'a yayılmış ve burada birçok entelektüeli kendine çekmiş ve çok daha ince bir teolojik harekete dönüşmüştür. İstanbul'dan doğuda Küçük Asya'ya, batıda Akdeniz boyunca Dalmaçya, İtalya ve Güney Fransa'ya kadar yayılmıştır. Aynı sapkınlık Batı Avrupa topraklarına -farklı isimler altında (örneğin, Katharlar ve Patarinler)- XII. yüzyılın ikinci yarısından itibaren gelişmiştir. XIII. yüzyılın başlarında Fransa'da başta Aziz Dominik olmak üzere Katoliklerin uğraşları sonucunda yok olmuş fakat XIV. yüzyılda İtalya'da varlığını sürdürmeye devam etmiştir. ${ }^{26}$

22 Hamilton vd., Bizans Döneminde, s. 75; 210.

23 Fine, The Early Medieval Balkans, s. 175.

24 Dua edenler ve namaz kılanlar anlamına gelen Messilianlar, çok az bilinen IV. ve V. yüzyıllarda bazı Bizans ve Suriye, Urfa manastırlarında gelişen coşkulu bir mezheptir. Albayrak, Bogomilizm, s. 89-90.

25 Dmitri Obolensky, The Bogomils: A Study in Balkan Neo-Manichaesim, Middlesex: Cambridge University Press, 1972, s. 53.

26 Janko Lavrin, "The Bogomils and Bogomilism", The Slavonic and East European Review, Vol. 28, 23, (Aralık 1929), s. 270; Lambert, Ortaçağda Dinsel Sapkınlıklar, s. 90; Murat Serdar, "Kathar Sapkınlığına Karşı Amansız Mücadelenin Dini Aktörü", Cappadocia Journal of History and Social Sciences, Vol: 11, (October 2018), s. 278-287. 
Ortaçağ'da batıda tezahür eden sapkınlıkların inançlarını ve örgütlenmesini tanımlayan pek çok kaynak mevcuttur. Bu belgeler, batılı düalistlerin Bogomillerle birçok inancı paylaştıklarını göstermektedir. Engizisyon kaynakları Batı sapkınlığının Bulgaristan'da ortaya çıktığını belirttiğinden, görüşlerdeki bu benzerlikler şaşırtıcı değildir. Sonuç olarak araştırmacılar, Ortaçağ düalizminin ortak bir resmini vermek için doğu ve batı kaynaklarında bulunan malumatı birleştirmişlerdir. Daha sonra bu tablo Bulgar Bogomilizmi hakkındaki bilgilerimizdeki boşlukları doldurmak için kullanılmıştır. ${ }^{27}$

Bununla birlikte Batı'da gelişmekte olan yeni doktrinel fikirler belgelenebildiğinden, örneğin güney Fransa'da bulunan her inancın zorunlu olarak Bulgaristan'da da olduğu çıkarımı yapılamaz. Bu nedenle, büyük olasılıkla bu tür karmaşık resimler Bulgaristan için tamamen doğru değildir. Bu eksikliği akılda tutarsak, karmaşık resmin bir özeti, okuyucuya en azından Bogomillerin, insanın dünyadaki yaşamını nasıl gördükleri ve kurtuluş aradıklarını kabaca anlatabilir. Bu sapkınlık düalist bir dünya görüşüne sahipti yani iki ilkeye inanmaktadır; biri iyi (ruh dünyası ile özdeşleşmiş, bu dünyayı ve ruhlarımızı yaratan) ve diğeri kötülük (görünür dünyayı ve insan bedenlerini yaratan madde ile bağlantılı). Çeşitli kozmolojik mitleri vardır fakat temel fikirleri şöyleydi: Tanrı'nın iki oğlu vardı: Şeytan ve İsa. Her ikisi de tamamen ruhanî varlıklardı. Şeytan isyan etti ve maddeyi yarattı, dünyayı ve insanları da dâhil olmak üzere her şeyi o yarattı. Bununla beraber şeytan, kendi başına yaşam yaratamazdı, bu yüzden manevi babadan yarattıklarına ruh üflemesi için yardım almak zorunda kaldı. ${ }^{28}$

Bunun nasıl yapıldığına dair farklı hikâyeler vardır; bunlardan en yaygın ikisi, Tanrı ya kil adama nefes verir ya da şeytan kilden bir meleği hapseder. Eski Tanrı'nın nefesiyle melek, madde içinde hapsedilen ruhlarımıza dönüşür. Böylece yaratılış, Eski Ahid'in Tanrı'sı olan Şeytan'la özdeşleştirilir; bu sebeple düalistler Eski Ahid'i reddederler. Bu arada iyi ilke ve iyi oğul (Mesih) manevi krallıkta kalırken, dünyevî bedenlerde hapsedilen insan ruhları, maddeden kaçmak ve ona geri dönmek isterler. Nasıl olduğunu bilmediklerinden, Tanrı Mesih'i yapılış şeklini açıklamak için bir mesajla dünyaya gönderir fakat Mesih, tamamen ruhtu. 0 sadece bir insan gibi göründü ama O'nun kendisine atfedilen dünyevî deneyimlerin hiçbirine girmemiştir. Böylece 0 gerçekten doğmadı ve gerçekten ölmedi çünkü maddenin kötülüğünü üstlenemedi. Maddeden nasıl kaçılacağına dair mesajı İncil'de mevcuttur. Basitleştirilmiş biçimde şunları öğretmiştir: Yeryüzünde üreme ve günah yoluyla ruhlar sürekli olarak bu dünyaya bağlandı; sonuç olarak bir insan öldüğünde ruhu başka bir dünyevî bedende yeniden doğar. Cennete girmenin tek yolu, her gün defalarca dua etmek ve sadece manevi ayinleri uygulamak, (tüm maddi nesnelere ibadet etmekten, su ile vaftizden, haçlardan, ikonlardan, kiliselerden vb.) çileci bir hayat

27 Lavrin bunu Bulgaristan'ın coğrafî konumuna bağlamaktadır çünkü Bulgaristan Doğu ile Batı ticareti arasında bir köprü vazifesi görmektedir. Lavrin, "The Bogomils”, s. 272.

28 Cosmas'ın tanımladığı Bogomiller ılımlı düalistlerdi. Onlar iki oğlu olan tek Tanrı'ya inanırlardı: Büyüğü Hz. İsa, küçüğü şeytan. Bkz. Hamilton vd., Bizans Döneminde, s. 74 
sürmektir; kişi cinsel ilişkiden (ve evlilikten) ve cinsel eylemlerden (örn. zevkten) doğan her şeyden kaçınmalıdır. ${ }^{29}$

Elbette böyle çileci bir yaşam çoğu insan için imkânsızdır; böylece Batı toplumu iki düzene ayrılmıştır: ilki ruhani bir kabule katlananlar, ikincisi Kutsal Ruh'a ve inananlara sahip olan kusursuzlar (rahiplik). İnananlar normal hayatlara öncülük ettiler, daha sonra (dul ya da ölüm yataklarında) yaşamın geç saatlerinde manevi kabul aldılar ve rahip oldular. Eğer kişi bu kabulü alamazsa, ölümünden sonra insan olarak yeniden doğacaktır. Rahiplik, göçebe çileci bir yaşam sürmüş, el emeğine dayalı bir işte çalışmamış ve inananlar tarafından beslenmişlerdir. Şayet günah işlerlerse, yeniden başlamaları gerekiyordu. Batılı düalistler, bunun gibi her biri bir piskoposun altında birçok “kiliseye” bölünmüşlerdi. ${ }^{30}$

Yukarıda özetlenen karmaşık resmin bazı yönleri Bulgar kaynaklarında desteklenmez, bu sebeple Bulgaristan açısından bu çıkarımları yapmak doğru olmayabilir. Belirtildiği gibi, bu karmaşık resim, X-XIV. yüzyıllar arasında birçok farklı yerden (Bulgaristan, Anadolu, Güney Fransa, kuzey İtalya) çizilmiştir. Bulgaristan ile Batı sapkınlıkları arasında çeşitli bağlar var gibi görünse de bu bağlar belgelenmedikçe Bulgaristan'da bunların dışında farklı bir inancın var olduğunu iddia edemeyiz.

Bogomillerin bu karmaşık resimde bulunan belirli inançlara sahip olup olmadıklarına itiraz edilmesine rağmen Bogomilizm teolojisi ve genel ruhu hakkında hâlâ önemli miktarda bilgi Bulgar kaynaklarından edinilmektedir. Bununla birlikte, bazı akademisyenler ayrıntılı açıklamalar sunsa bile, sapkınlığın diğer yönleri hakkında çok az şey bilinmektedir. ${ }^{31}$ Karmaşık resimde verilen liderliğin organizasyonu başlıca yabancı kaynaklardan alınmıştır; bu durum Bulgaristan için de doğru olabilir ama kanıt olmadığında spekülatif olarak kalmıştır. Yine de Bogomilizm hareketi Bulgaristan'da ortaya çıktığı için, Batı'da bulunan birçok örgütsel yönün Bulgaristan'da aynı veya benzer tezahürlere sahip olması muhtemeldir. Aslında, Batı'da bulunan kurumsal yapının çoğunun Bulgaristan'dan bile kaynaklanmış olma ihtimali yüksektir.

29 Bogomillere göre fiziksel evlilik zinadır. Bogomilizm'de seçkinler evlenemezler. Sıradan insanlar ise evlenebilirler. Ancak onların mükemmel/seçkin olmak için çaba göstermeleri gerekir. Bogomiller, evliliği bir sakrament olarak değil de toplumsal bir ihtiyaç olarak görürler. Hıristiyanlık içerisinde din adamlarının evlenmesi konusunda farklı uygulamalar mevcuttur. Katolik din adamları evlenmezken Ortodokslarda sadece üst düzey din adamları evlenmezler. Evlilik konusunda Bogomillerin Maniheizm'den etkilendikleri göze çarpmaktadır. Bkz. İsmajil Hodziç, Bogomilizm ve Bosna-Herkes Bogomilleri, Yayımlanmamış Yüksek Lisans Tezi, Ondokuzmayıs Üniversitesi Sosyal Bilimler Enstitüsü Felsefe ve Din Bilimleri Anabilim Dalı, Samsun, 2007, s. 88.

30 Bu konuda çeşitli görüşler olsa da Nathalie Luca'nın mezheplerin ortaya çıkışı üzerine yaptığı tespitini burada paylaşmanın yerine olacağını düşünüyoruz: “Bir toplumun politik, ekonomik ve toplumsal çerçevesinin, din duygusu ve dinin gelişimi üzerinde önemli bir rol oynadığı görülür. Toplumsal dengesizlik, baskın dini görüşün aranılan huzuru sağlayıp sağlamadığı sorusunu gündeme getirerek, arayışların ötelere kaymasına yol açar. Böylece farklı kültür çağlarının dinsel modellerine karşı bir duyarlılık gelişir. Fakat mevcut dinî inanç da eleştiriler, hatalardan arındırılmalar, yeni çözümler ışığında bir reforma tabi tutulabilir. Kendisine yönelik suçlamaları ortadan kaldırmakta güçsüz kalan baskın görüş bölünmeye mahkûmdur."Bkz. Nathalie Luca, Mezhepler, (Çev. M. Nedim Demirtaş), Ankara: Dost Kitabevi Yayınları, 2005, s. 20.

31 Fazla iddialı görüşleri olan Tarihçi Çog'a göre Bogomilizm, tenkitçi, akılcı, hümanist ve mücadeleci karakterleriyle Ortaçağ Avrupası'nı siyasî, felsefî ve sosyal hayatına yön verebilecek kadar etkili olmuştur. Bkz. Mehmet Çog, "İslam-Bizans İlişkileri Bağlamında "Pavlikanlar” Üzerine Bir Değerlendirme”, Fırat Üniversitesi Illahiyat Fakültesi Dergisi, 13:2, (2008), s. 83. 
Bulgar Bogomillerinin batıdakine benzer bir törenle manevi kabul töreni uyguladıkları biraz güvenle önerilebilir. Nazarius adlı bir İtalyan düalist piskoposunun 1190 civarında Bulgaristan'a kabul almak için gittiği biliniyor. ${ }^{32}$ Ayrıca, yaklaşık 1250 yılında bu konuda yazan bir İtalyan araştırmacı Rayner Sacconi, Doğu'da birlikte toplamda 500 rahibe sahip altı düalist kilise (Trakya'da Bulgaristan ve Dragovica dâhil) olduğunu belirtmektedir. Dolayısıyla, XII. ve XIII. yüzyılların sonlarında, batılı düalistler gibi Bulgarların rahiplere sahip oldukları açıktır. Bunun geç bir yenilik olduğuna inanmak için hiçbir neden yoktur. Görünüşe göre Cosmas, bazı Bulgar Bogomillerinin halka öncülük ettiğini, el emeği yapmadığını ve başkaları tarafından beslendiğini belirttiğinde, aslında bölgedeki rahiplere atıfta bulunuyor gibi görünmektedir. Bununla birlikte XII ilâ XIV. yüzyıllar arasındaki Batılı meslektaşları gibi Bogomillerin bir veya daha fazla büyük piskoposun yönetimi altında organize bir hiyerarşisi olup olmadığı bilinmemektedir. Söylenebilecek olan tek şey, Baril'in 121 1'deki Sinod'unun, diğerlerinin yanı sıra birçok bilginin makul bir şekilde bir tür piskopos olduğunu önerdiği Sardika'nın (günümüzde Sofya) bir dedesini kınamasıdır (Ded, zaman zaman önemli bir yaşlı için kullanılan bir Slav dedesi kelimesidir.) ${ }^{33}$

\section{Bogomilizm'in Sosyal Yönü ve Önemi}

Düalist hareketin Bulgaristan'ın köylü toplumunda nasıl bir çekiciliğe sahip olacağı sorusunu çözmek için çok az bilginin olduğu açıktır. Toplumsal bir hareket miydi (dindar olmayan sebeplerden dolayı büyük bir takipçi çekmiş olabilir) yoksa sadece küçük bir mezhep miydi? Bogomilizm'in sosyal bir hareket olduğu fikrini desteklemek için, Cosmas'ta üstlerinize vb. itaat etmeme hakkında sadece bir kısa paragraf vardır. ${ }^{34} \mathrm{Bu}$ özdeyişler besbelli vaaz edilmiştir ama söylenebilecek her şey bu kadardır. Din değiştirenlerin resimde etkili olup olmadıkları bilinmemektedir. Bogomiller, Ortaçağ'da Bulgaristan'daki muhtelif sosyal protestolara önderlik etmedikleri ya da aşağıdaki gibi yer almadıkları için, Bogomilizm'i toplumsal bir hareket olarak değerlendirmemiz zordur. Kaynaklar Bizans'a karşı herhangi bir savaşta aktif olan veya imparatorluğa karşı isyan eden Bogomillerden bahsetmediği için - Bulgaristan Bizans egemenliği altındayken - ulusal (nativistik) bir hareket olarak Bogomilizm için bir kılıf uydurmak daha da zordur. ${ }^{35}$

32 Bulgar dinsel kardeşlik grubu liderlerinden birisinin 1190 yılında Concorezo'daki Katharlar'ı ziyaret ederek, yerel Kathar Piskoposu Nazariusa Bogomillerin ana apokrif İncili olan Yuhanna İncili'ni (Gizli Kitap) hediye ettiği ve bunun da muhtemelen daha sonra Latinceye çevrildiği bilinmektedir. Görüldüğü üzere, Bulgar Bogomilleri, İtalyan kardeşlerine doktrinlerini yayma noktasında ihtiyaç duydukları literatür desteğinde de bulunmuşlardır. Bkz. Hodziç, Bogomilizm, s. 37.

33 Fine, The Early Medieval Balkans, s. 178.

34 Hamilton vd., Bizans Döneminde, s. 231.

35 Ünlü Bizans kronikçisi Anna Komnena Bogomillerin devlete karşı olan tutumlarını şöyle aktarmaktadır: "loannés Tzimiskés (Çimiskes), hasımları olan Manici (burada kastettiği Paulosçular ile Bogomillerdir) sapkınları bizim müttefiklerimiz durumuna getirdikten sonra, göçebe İskitlerin karşısına, onlarla baş edebilecek güçler kimliğiyle yerleştirdi; o zaman kentler, berikilerin (İskitlerin) sık sık yaptığı talan akınlarından kurtularak, yeniden soluk aldı. Ne var ki huyları gereği bağımsız ve kendi başına buyruk olan Maniciler, alışılageldikleri gibi davranır oldular ve kendi doğal yapılarına döndüler. Filibe halkı, çok küçük bir azınlık dışında, Manici olduğu için, oradaki Hıristiyanları eziyorlar, mallarını talan ediyorlar ve imparatorun gönderdiği ulakların sözlerine ya pek az aldırıyor ya da hiç aldırmıyorlardı. Sayıları artıp duruyordu ve Filibe'nin tüm çevresi sapkın olmuştu." Bkz. Anna Komnena, Alexiad, s. 473. 
Fine'a göre ister ulusal ister sosyal olsun, bazı dünyevî hedefler için pratik bir hareket olmasaydı, köylülerin bu harekete neden katılacağını anlamamız zor olurdu. Neredeyse hiçbir kaynak onların yaptıklarını göstermez. Bu sebeple, muhtemelen Bogomilizm'in öğretilerinin sosyal yönleri olmasına rağmen, bunun bir köylü hareketi veya sosyal hareket haline gelmediği sonucuna varmalıyız. Bu gerçekler, Bulgaristan'daki Bogomiller hakkında sadece bir avuç dağınık kaynak olması -bazen tam anlamıyla çağdaş olmasa da- ve bu kaynakların hiçbirinin ciddi bir devamının olmadığı gerçeği ile birleştiğinde -bazı devletlerde Bogomilizm'i geniş bir alana dağılmış olmasına rağmen (örneğin, Bulgaristan genelinde)- Bogomilizm'i küçük bir hareket olarak değerlendirmek için güçlü gerekçeler var gibi görünmektedir. ${ }^{36}$

Bogomiller Bulgar tarihindeki herhangi dönüm noktası oluşturacak bir siyasi veya sosyal olayda rol oynamadıkları için, Bogomilizm'in Bulgar tarihi üzerinde muhtemelen çok az etkisi olmuştur. Bu yüzden, tüm üyelerini genel olarak dini bir doktrine çeken ilginç fakat küçük bir mezhep olarak görülmesi gerektiğini düşünmekteyiz. Bu Bulgar düalistleri, Akdeniz bölgesindeki düalist hareketin tohumlarını ekmede önemli bir rol oynamışlardır. Böylece yabancı düalistler arasında büyük bir prestij kazanmışlardır.

Kanaatimizce Bogomillerin Bulgaristan'dan İtalya'ya hatta Fransa'ya kadar yayılmış olmaları ve çeşitli işkencelere maruz kalmış oldukları gerçeğini göz önünde bulunduracak olursak, çeşitli toplumsal olaylara kaçınılmaz bir şekilde müdahil olduklarını fakat yetersiz kaynak eksikliği sebebiyle ve de ilerleyen dönemlerde yapılacak çalışmalarla bu olayların gün yüzüne çıkacağı umudu taşımaktayız.

\section{Bogomilizm'in Bulgaristan'a Yansımaları}

Yukarıda da değindiğimiz gibi Bogomilizm Bulgaristan topraklarında, Çar Peter zamanında doğmuş ve özellikle kırsal kesimde yayılmıştır. Yeni bir akımın ortaya çıkmasından ve ileride kendisine yönelik tehdit unsuru olmasından çekinen Çar, derhal doğuda Bogomillere karşı amansız bir kılıç mücadelesi içinde olan İstanbul Patriği Theophylact'a iki mektup göndermiş ve bu yeni heretik akıma karşı önlem alınmasını istemiştir. ${ }^{37}$ Devam eden süreçte Bogomiller ciddi baskılara ve işkencelere maruz kalmışlar, zincirlenmişler ve hücrelere atılmışlardır. ${ }^{38}$ Theophylact bu akımı Maniheizm ile Pavlosçuluğun bir karşımı olarak tanımlamıştır. Bununla birlikte Pop Bogomil bu mezhebin ortaya çıkışında aktif rol oynadığı için Bogomilizm adını almıştır. ${ }^{39}$

36 Bu noktada Fine, Garsoïan'a katılmadığını dolaylı olarak belirtmektedir çünkü Garsoïan Bogomilizm'in sosyal bir hareket olduğunu ileri sürerken Fine ise sosyal bir doktrinlerinin olmasına rağmen sosyal hayatta rol almadıklarını ifade etmektedir. Bkz. Fine, The Early Medieval Balkans, s. 179.

37 Basil Chulev, The Bogomils in Macedonia-Medieval Root of Protestantism, Renaissance and Socialist Movements The secret Books of Bogomils. Macedonia: Skopje, 2015, s. 14.

38 Turgut Derinkök, Bogomillerin 1118 yılında İmparator Aleksios Komnenos'un buyruğu ile Sinod Meclisi önünde yargılanıp diri diri yakıldıklarını iddia etmektedir. Bkz. Turgut Derinkök, Tampliye Şövalyeler: Ortadoğu'da Dini Inanışlar ve Düşünceler, İstanbul: Alfa Yayınları, 2005, s. 392.

39 Albayrak, Bogomiller, s. 141-142. 
Destekçilerinin ağırlıklı olarak Bulgar ve Slavlardan oluşması bu akımın millî bir kimlik kazandığı yorumunun getirilmesine olanak sağlamıştır. Bu akımı kabul edenler her ne kadar Hıristiyan kökenli olsalar da henüz geleneklerinden, eski dinlerinden kopamamışlar sadece ismen Hıristiyan hayatı sürmüşlerdir. Bu nedenle yeni akımın hem geleneklere bağlı hem de Hıristiyanlığın bir türevi olması özellikle kırsal kesimde taban oluşturmasına önayak olmuştur.

X. ve XI. asırda Bulgaristan topraklarında çeşitli baskılar mevcuttu. Bizans İmparatorluğu'nun genişleme çabaları, Bogomilleri de ister istemez etkilemiştir. Normalde Bulgar Çarı'na ve yerel beylere karşı tavır alan Bogomiller, dış tehlikelere karşı ortak hareket edip vatan savunmasına geçmişlerdir. Bu sebeple Çar Samouil (997-1014) döneminde Bogomillere karşı herhangi bir baskı veya işkenceden bahsedilmemiştir. Aynı şekilde Bogomillerden de bu dönemde devlete karşı herhangi bir tepki gelmemiştir. Neticede Bizans'ın Bulgar topraklarını işgal etmesi, doğal olarak kendi yönetimini bölgeye yerleştirmesi, ardından gelen Peçenek, Uz, Kuman ve Norman istilaları Bizans karşıtı hareketleri sosyal anlamda alevlendirmiştir. Yabancı işgallere karşı yurtlarını savunmak için yönetimle ortak hareket etmişlerdir. Bu durum XI. yüzyılda kaleme alınmış olan “Peygamber Yeşaya Efsanesi” adlı bir çalışmada Bogomilerin dünya nimetlerinden uzakta yaşamalarını ve devlet adamlarının politikalarını övme gibi konuları içermektedir.40

Bizans'ın Bogomilleri, kanonik Hıristiyanlığın dini figürleriyle çelişmesi ve bunların Bizans tacına karşı hazırlanmış bir komplo olarak görmesinden dolayı Bogomiller genel olarak Bizans'a karşı bir düşmanlık beslemişlerdir. ${ }^{41}$ Bu düşmanlık zamanla büyümüş ve 1040 yılında isyana dönüşmüştür. İsyan ilk etapta Bulgaristan'ın güneybatısında başlamış fakat kısa sürede Bizans İmparatorluğu tarafından bastırımıştır. Bogomiller bu isyanın ardından yurtlarını terk etmeye zorlanmışlardır. Yurtlarını terk eden Bogomillerin ağırlıklı olarak Sicilya bölgesine kaçtıkları düşünülmektedir. Bununla birlikte 1079 yılında Sofya bölgesinde ikinci bir ayaklanma daha patlak vermiştir. Bu ayaklanma Bogomil ve Pavlosçuların ortak ayaklanması olup devlet baskısına karşı gerçekleşmiştir. Özellikle kilisenin Bogomil taraftarlarına yaptığı baskı neticesinde, Bogomiller Sofya Piskoposu Mihail'i öldürmüşlerdir. ${ }^{42}$

11 Şubat 1211 tarihinde Çar Boris'in önderliğinde Bogomil üyelerini kınamak için Bulgar Kilisesi'nde bir sinod toplanmıştır. Bu sinodun toplanmasında Roma Papası'nın da etkisi olmuştu. 0 dönemde Papalık koltuğunda bulunan Papa III. Innocent'in, Bulgar topraklarındaki sapkınların durumunu öğrenmesi için gönderdiği elçi olarak gönderdiği kardinalden hemen sonra sinodun toplanmış olması bunun delili niteliğindedir. Bulgaristan'da olduğu gibi Sırbistan, Dalmaçya, Bosna gibi diğer ülkelerde de faaliyet göstermişlerdir. Sırbistan'da yayılmaya

40 Alexandar Nikolov, "Patriotic and 'Proto-National' Motives in Late Medieval and Early Modern Bulgarian Literature: The Contexts of Paisij Hilendarski”, Whose Love of Which Country?, (Ed. Balazs Trencsenyi \& Marton Zaszkaliczky), Leiden: Brill, 2010 s. 614.

41 Maja Angelovska-Panova, “Turning Towards Heresy: Bogomils and Self-Defence”, Nottingham Medieval Studies, 63 (2019), s. 87.

42 Albayrak, Bogomiller, s. 145-146. 
başladıklarında Bulgaristan'da olduğu gibi burada da kral Stefan Nemanje onlara karşı bir kilise konseyi toplamıştır. Bu gibi faaliyetler Bogomillerin kendilerini gizlemelerine ya da bu toprakları terk edip daha rahat yaşayabilecekleri topraklara göç etmelerine sebebiyet vermiştir. ${ }^{43}$

Bu iki ayaklanma dışında bildiğimiz kadarıyla farklı büyük bir isyan olmamıştır. Bunun dışında Bulgaristan coğrafyasında daha uzun bir süre varlığını sürdürecek olan Bogomilizm taraftarları yakalandıkça çeşitli işskencelere maruz kalmaya devam etmişlerdir. 0 dönemlerin meşhur idam yöntemlerinden olan yakılarak katledilme, Bogomil taraftarlarının da maruz kaldıkları bir idam yöntemi olmuştur. Bununla birlikte XV. yüzyılda Türklerin bölgeyi fethetmesi ile Bogomil taraftarlarının kitlesel olarak İslâmiyet'e geçtikleri de görülmektedir. ${ }^{44}$

\section{Sonuç}

Ortaçağ Bulgaristanı'nda heretik bir hareket olarak ortaya çıkan Bogomilizm, köken olarak henüz Hıristiyanlığı tam olarak anlayamamış, geleneklerine bağlı kimseler tarafından kabul görmüş ve Bulgar Çarı'nın uyguladığı yanlış politikalar neticesinde kısa sürede yayılmıştır. Tabanını genel olarak kırsal kesimde bulan bu akım, sadece Bulgaristan ile sınırlı kalmamış Anadolu'dan Fransa'ya kadar geniş bir coğrafyada yayılmıştır.

Bogomillerin ortaya attıkları Tanrı ve Şeytan ilişkisi kırsalda yaşayan halk tabanında kabul görmüş fakat taraftarları Ortodoks ve Katolik kiliseleri tarafından heretiklikle suçlanıp çeşitli işkencelere ve idamlara maruz kalmışlar. Her ne kadar zor zamanlardan geçmiş olsalar da inançlarına sıkı sıkıya bağlı kalmışlar ve baskılardan kaçabilmek için sürekli olarak saklanmışlardır.

En nihayetinde Osmanlı Devleti'nin XV. yüzyılda bölgeye gelmesiyle, bu mezheplerin İslâmiyet ile tanışmaları, onları bu dine yaklaştırmış ve kitlesel olarak İslâmiyet'e geçmelerini sağlamıştır. Buradan da anlayacağımız gibi tarih boyunca baskı, şiddet, zorlama gibi yöntemler bu tür hareketleri sindirmemiş sadece yeniden gün yüzüne çıkabilecekleri günün gelmesini beklemiştir.

Peer-review: Externally peer-reviewed.

Conflict of Interest: The author has no conflict of interest to declare.

Grant Support: The author declared that this study has received no financial support.

Hakem Değerlendirmesi: Dış bağımsız.

Çıkar Çatışması: Yazar çıkar çatışması bildirmemiştir.

Finansal Destek: Yazar bu çalışma için finansal destek almadığını beyan etmiştir.

43 Daha geniş bilgi için bkz: Elena Ene D-Vasilescu, "Heavenly Sustenance in Patristic Texts and Byzantine Iconography", New Approaches to Byzantine History and Culture, London: Palgrave Macmillan, 2018, s. 145-146.

44 Ahmet Yaşar Ocak, Osmanlı Toplumunda Zındıklar ve Mülhidler: XV-XVII. Yüzyıllar), Tarih Vakfı Yurt Yayınları, İstanbul, 2016, s. 342; Ayrıca Bulgaristan'daki bazı Bogomil mezarlarının Türk mezarlarına benzerliği de bu konuyla alakalı gibi görünmektedir. Bkz. Emel Esin, "Bosna-Hersek'de Bogomillere Atfedilen, XIII-XVI. Asırlardan Lahdler ile Anadoludaki XII-XIV. Yüzyıllardan Müşahhas Tasvirli Türk Mezar Taşları Arasında Bir Mukayese”, Orijentalni Institut u Sarajevu, Vol. 30, 1980, s. 138; Tabii ki Türklerin Bogomil gibi heretikler üzerinde baskı kurduğunu iddia eden araştırmalar da mevcuttur. Bkz. John Smith, Christianity's Greatest Controversy: Prelude to Genocide, Victoria: Archangel Publishing, 2004, s. 191. 


\section{Bibliyografya}

Albayrak, Kadir, Bogomilizm ve Bosna Kilisesi, İstanbul: Emre Yayınları, 2005.

Angelovska-Panova, Maja, "Turning Towards Heresy: Bogomils and Self-Defence”, Nottingham Medieval Studies, 63 (2019), s. 81-94.

Angold, Michael, "The Bogomils", Church and Society in Byzantium under the Comneni, 1081-1261, Cambridge: Cambridge University Press, 1995, s. 468-502.

Anna Komnena, Alexiad, (Çev. Bilge Umar), Ankara: İnkılâp Kitabevi Yayınları, 1996.

Aydın, Mehmet, "Hıristiyanlık: Mezhepler ve Tarikatlar”, C. XVII. Türkiye Diyanet Vakfı İslam Ansiklopedisi, İstanbul, 1998, s. 353 - 358.

Chulev, Basil, The Bogomils in Macedonia-Medieval Root of Protestantism, Renaissance and Socialist Movements The secret Books of Bogomils. Macedonia: Skopje, 2015.

Çog, Mehmet, “İslam-Bizans İlişkileri Bağlamında “Pavlikanlar” Üzerine Bir Değerlendirme”, Fırat Üniversitesi Ilahiyat Fakültesi Dergisi, 13:2 (2008), s. 73-87.

Derinkök, Turgut, Tampliye Şövalyeler: Ortadoğu'da Dini Inanışlar ve Düşünceler, İstanbul: Alfa Yayınları, 2005.

D-Vasilescu, Elena Ene, Heavenly Sustenance in Patristic Texts and Byzantine Iconography, London: Palgrave Macmillan, 2018.

El-Mi'veş, Lütfi, “Bogomiller, Hıristiyanlar ve Bosna”, (Çev. Kadir Albayrak), Tezkire, 36-37 (Ocak/Nisan 2004), s. 183-184.

Esin, Emel, “Bosna-Hersek'de Bogomillere Atfedilen, XIII-XVI. Asırlardan Lahdler ile Anadoludaki XIIXIV. Yüzyıllardan Müşahhas Tasvirli Türk Mezar Taşları Arasında Bir Mukayese", Orijentalni Institut u Sarajevu, Vol. 30, 1980, s. 107-138.

Fine, John Van Antwerp, The Early Medieval Balkans: A Critical Survey from the Sixth to the Late Twenlfth Century, Michigan: The University of Michigan Press, 1991.

Garoian, Nina G., Byzantine Heresy: A Reinterpretation, Washington: Dumbarton Oaks Center for Byzantine Studies, 1971.

Groote, Marc de, "An Anonymous Sermon against the Hagarenes, the Bogomils, and the Jews", The Harvard Theological Review, Vol. 97, No. 3 (July 2004), s. 329-334+336-351.

Hamilton, Janet; Hamilton, Bernard; Stoyanov, Yuri, Bizans Döneminde Hıristiyan Düalist Heretikler (650-1405), (Çev. Leyla Kuzucular), Ankara: Yurt Kitap-Yayın, 2011.

Hodziç, İsmajil, Bogomilizm ve Bosna-Herkes Bogomilleri, Yayımlanmamış Yüksek Lisans Tezi, Ondokuzmayıs Üniversitesi Sosyal Bilimler Enstitüsü Felsefe ve Din Bilimleri Anabilim Dalı, Samsun, 2007.

Kaçar, Turhan, Geç Antikçağ'da Hıristiyanlık, İstanbul: Arkeoloji ve Sanat Yayınları, 2009.

Kaygusuz, İsmail, “Anadolu'dan Batı Avrupa'ya, Aykırı İnanç ve Düşünce Geleneği ve Alevilikteki Kalıtlar”, Müslüman ve Hıristiyanlığın InançÖğretilerinde Öteki Gerçekler, İstanbul: Su Yayınları, 2006, s. 173-257.

Lambert, Malcolm D., Ortaçağda Dinsel Sapkınlıklar, (Çev. Erdem Gökyaran), İstanbul: Kabalcı Yayınları, 2015.

Lavrin, Janko, "The Bogomils and Bogomilism", The Slavonic and East European Review, Vol. 28, No. 23 (Aralık 1929), s. 269-283.

Luca, Nathalie, Mezhepler, (Çev. M. Nedim Demirtaş), Ankara: Dost Kitabevi Yayınları, 2005. 
Nikolov, Alexandar, "Patriotic and 'Proto-National' Motives in Late Medieval and Early Modern Bulgarian Literature: The Contexts of Paisij Hilendarski", Whose Love of Which Country?, (Ed. Balazs Trencsenyi \& Marton Zaszkaliczky), Leiden: Brill, , 2010, s. 611-628.

Nurigian, Giorgio, The Macedonian Genius Through The Centuries, London: David Harvey Publishers, 1972.

Obolensky, Dmitri, The Bogomils: A Study in Balkan Neo-Manichaesim, Middlesex: Cambridge University Press, 1972.

Ocak, Ahmet Yaşar, Osmanlı Toplumunda Zındıklar ve Mülhidler: XV-XVII. Yüzyıllar), İstanbul: Tarih Vakfı Yurt Yayınları, 2016.

Peters, Edwar, Heresy and Authority in Medieval Europe, Phiadelphia: University of Pennsylvania Press, 1980.

Serdar, Murat, “Kathar Sapkınlığına Karşı Amansız Mücadelenin Dini Aktörü”, Cappadocia Journal of History and Social Sciences, Vol: 11, (October 2018), s. 278-287.

Smith, John, Christianity's Greatest Controversy: Prelude to Genocide, Victoria: Archangel Publishing, 2004.

Vassilev, Vassil A., Bulgaria 13. Centuries of Existence, Sofia: Sofia Press, 1979. 
